\title{
OS MEANDROS DA PRESERVAÇÃO E CONSERVAÇÃO: O LABCOR: SOB A VISÃO DAS MONITORAS
}

\author{
Orientando: Ana Cecília de Brito Valença Guimarães \\ Graduada em Biblioteconomia
}

Orientador: Eliane Bezerra Paiva

Doutora em Linguística

Professora do DCI/PPGCI/UFPB

paivaeb@gmail.com

\section{Resumo}

Analisa a importância do Laboratório de Preservação e Conservação (LABCOR) da Universidade Federal da Paraíba a partir da visão dos monitores da disciplina de Preservação e Conservação de Acervos. Descreve desde os primórdios após a descoberta da escrita a importância da preservação e conservação de materiais bibliográficos e documentais no mundo e no país, promovendo a conscientização de uma conservação preventiva, mostrando sua relevância tanto para o conhecimento da história das civilizações, como para os dias atuais, e que com isso vejam refletidos no passado e possam construir sua identidade no futuro. Trata-se de uma pesquisa exploratória de caráter descritivo, com abordagem quanti-qualitativa, que utilizou como instrumento para a coleta de dados um questionário aplicado às monitoras do LABCOR. Concluise que, apesar da falta de alguns materiais necessários para o adequado ensino-aprendizagem na disciplina Preservação e Conservação de Acervos, o LABCOR é de extrema importância para a prática dos estudantes de Biblioteconomia e Arquivologia da UFPB.

Palavras-chave: Conservação preventiva. Restauração. Livros. Monitoria. LABCOR. 